\title{
SIPRESI: SISTEM INFORMASI PRESENSI SISWA SMP TAMAN SISWA BOGOR
}

\author{
Lydia Salvina Helling ${ }^{*}$, Helina Apriyani² \\ ${ }^{1}$ Sistem Informasi Akuntansi; ${ }^{2}$ Sistem Informasi Kampus Kota Bogor \\ Universitas Bina Sarana Informatika \\ 1lydia.lsh@bsi.ac.id, ${ }^{2}$ helina.hld@bsi.ac.id \\ ${ }^{*}$ ) Corresponding Author
}

\begin{abstract}
Abstrak
SMP Taman Siswa adalah salah satu lembaga pendidikan di kota Bogor yang masih mempergunakan pencatatan secara manual pada daftar presensi siswanya. Proses pencatatan presensi ini memerlukan waktu dalam menjalankannya dan rekapitulasi daftar kehadiran siswa pun terkadang hilang akibat kelalaian guru yang bertugas atau pihak staf tata usaha. Hal - hal tersebut yang mendasari dibuatnya Sistem Informasi Presensi Siswa sehingga dapat mempermudah guru dan bagian tata usaha dalam pengolahan data kehadiran para siswa. Laporan data kehadiran harian SiPreSi ini akan diberikan kepada orangtua melalui grup media sosial dalam memantau kehadiran anak - anak mereka pada setiap mata pelajaran yang diberikan. Kepala Sekolah pun dapat membuat keputusan tentang peraturan persentase kehadiran yang diberlakukan. Metode yang digunakan dalam penelitian ini yaitu dengan eksperimen yang pada tahap awalnya melakukan proses pengumpulan data melalui wawancara, observasi, dan studi literasi yang berkaitan dengan presensi siswa, Sedangkan pada proses pengembangan perangkat lunaknya mempergunakan RAD (Rapid Application Development). Hasil penelitian ini sangat berpengaruh terhadap keputusan - keputusan pihak sekolah terkait dengan kehadiran para siswa SMP Taman Siswa Bogor.
\end{abstract}

Kata kunci: Sistem Informasi, RAD ( Rapid Application Development), Pendidikan, Presensi

\begin{abstract}
Taman Siswa Middle School is an educational institution in the city of Bogor that still uses manual recording on the student attendance list. The process of recording this presence requires time in running it and the recapitulation of student attendance lists is sometimes lost due to the negligence of the teacher on duty or the administrative staff. These things that underlie the creation of Student Presence Information System so that it can facilitate the teacher, and the administration section in processing student attendance data. This SiPreSi daily attendance data report will be provided to parents through social media groups in monitoring the presence of their children in each given subject. The principal can also make decisions about the percentage of attendance regulations that apply. The method used in this research is an experiment at the initial stage of the process of collecting data through interviews, observations, and literacy studies relating to student presence while developing software using RAD (Rapid Application Development). The results of this study are very influential in school decisions related to the presence of students at Taman Siswa Bogor Middle School.
\end{abstract}

Keywords: Information Systems, RAD (Rapid Application Development), Education, Presence

\section{INTRODUCTION}

Presence in the Big Indonesian Dictionary (KBBI) has the meaning of attendance. In institutions and companies that have rules on the attendance rules of their members, the attendance list plays an important role in seeing how disciplined members are in carrying out the prescribed attendance and return rules. This was discussed in an article in a scientific journal entitled "Fingerprint-Based Employee Presence Application Development" (Haq, 2016) which describes that the attitude of discipline will provide maximum results in the face of progress and new challenges in the work. The government even made a National Discipline Movement (GDN) program from the Coordinating State Minister for Political and Security Affairs of the Republic of Indonesia on May 5, 1996, No.B/36/Menko/ Polkam/1995. The attendance list can also be a benchmark for evaluating the performance of members in carrying out their duties.

Taman Siswa Middle School is an educational institution in the city of Bogor that still uses a 
manual recording (Hermanto \& Jollyta, 2019) on the student attendance list. The teacher who teaches in a class will call each student in the class and give a mark on the attendance form. The process of recording this presence takes time to run so it is ineffective and inefficient (Darmawan et al., 2016). The results of the attendance recording will then be made recapitulation at the end of the month and end of the semester to determine the conditions for student participation in the midterm or final semester according to the provisions imposed by the school (Zebua \& Pristiwanto, 2017). Even the recapitulation of student attendance lists is sometimes lost due to the negligence of the teacher on duty in a class or administrative staff who keep the attendance list given by the teacher (Subiantoro \& Sardiarinto, 2018)

Student Presence Information System created to overcome the problems faced by Bogor Taman Siswa Middle School. This system will be designed by going through several stages of software development and testing so that it can run according to the needs of users.

\section{RESEARCH METHODS}

The research method used is an experimental model because there is a system development process from a manual system to an information system. Evaluation is also applied to ensure the information system runs as needed.

\section{Types of research}

This study uses the method of developing procedural models that are descriptive models by carrying out the steps that will be followed to produce products.

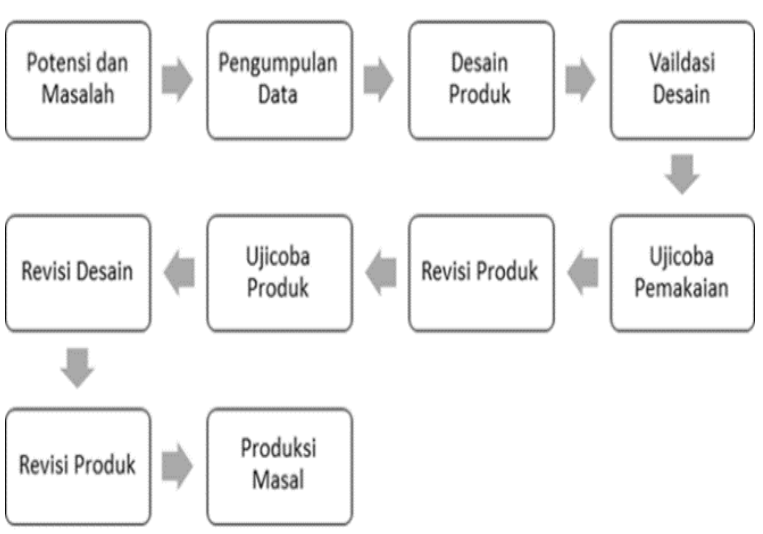

Source : (Hanafi, 2017)

Figure 1. Research and Development (R\&D) Model

This model adopts the Borg And Gall Research and Development model which will produce a particular product and test the effectiveness of the product (Haq, 2016). This research is intended to build a student attendance system at Taman Siswa Bogor Junior High School which was originally run manually into a presence information system that uses computers in processing data and even produces information that can be used by administrative staff and the school to make decisions.

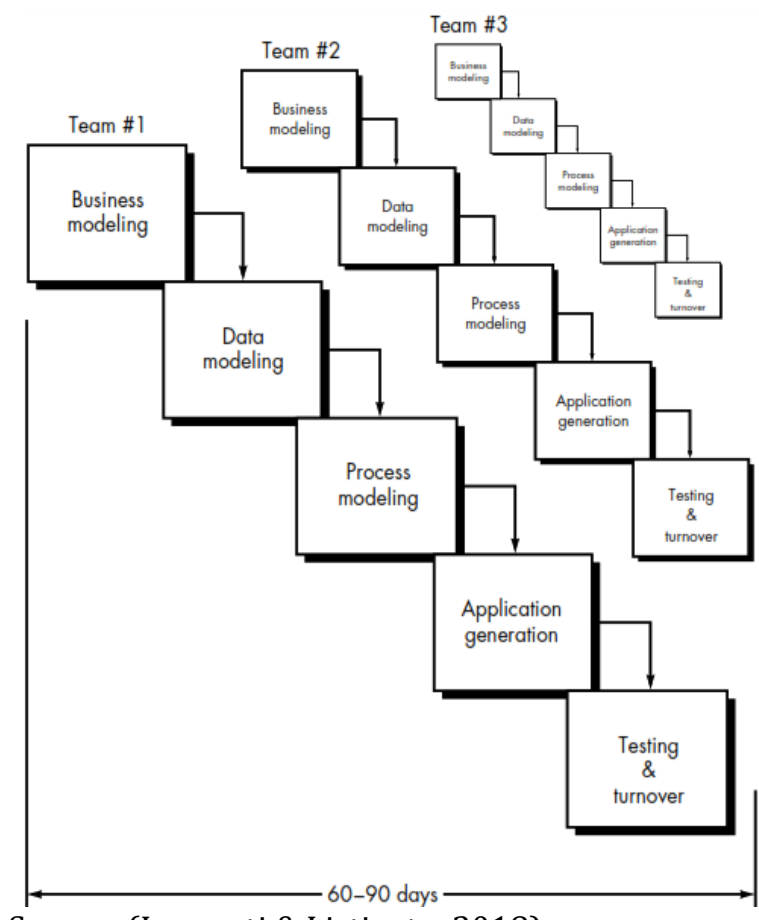

Source: (Irnawati \& Listianto, 2018)

Figure 2 RAD ( Rapid Application Development)

While the software development method applied in this study uses SDLC (System Development Life Cycle) type of RAD (Rapid Application Development) which is relatively more in line with the conditions encountered in the development of this system. RAD only requires a small scope and involves only a small team (Kusaeri et al., 2018) and the development process is relatively short (Kusaeri et al., 2018).

The steps in the RAD are as follows:(Irnawati \& Listianto, 2018)

1. Business Modeling

Modeling is done to model business functions to find out what information must be made, who has to make that information, how the flow of information is, what processes are associated with that information.

2. Data Modeling

Model what data is needed based on business modeling and defining attributes and their relationships with other data. 
3. Process Modeling

Implement defined business functions related to defining data.

4. Making the Application

Implement process and data modeling into a program. The RAD model strongly recommends the use of existing components if possible.

5. Testing and Substitution

Test the components that are made. If it has been tested, the component development team can move to develop the next component.

\section{Time and Place of Research}

This research took place in Taman Siswa Bogor Middle School located at Jl. Merdeka No.172, RT 01 / RW. 05, Ciwaringin, Kecamatan Bogor Tengah, Kota Bogor, West Java. Taman Siswa is the name of the school founded by Ki Hadjar Dewantara on July 3, 1922, in Yogyakarta. Park means a place to play or a place to learn, while students mean students. When it was first established, the Taman Siswa school was named the "National Onderwijs Institut Taman Siswa" which was a realization of Ki Hadjar Dewantara's ideas together with his friends in the Sloso Kliwon Circle of Friends. The Taman Siswa School is currently based at Balai Ibu Pawiyatan (Majelis Luhur) on Jalan Taman Siswa, Yogyakarta, and has 129 branch schools in various cities throughout Indonesia.

The study was conducted when students entered the classroom until the end of the lessons in the class, then continued by observing the recapitulation process that was carried out every day, month until before the exam took place.

\section{Research Targets or Targets}

Students, teachers, administrative staff, parents, and principals of Taman Siswa Junior High School were targeted in this study to obtain accurate information related to the existing attendance system.

\section{Procedure}

The procedure of the present system that has been implemented by the Taman Siswa Bogor Middle School is as follows:

1. Presence Record Procedure

Every day, the teacher will record the attendance or absence of students in class by calling one student's name on the attendance sheet. The attendance sheet is then collected every day by the administrative staff in the class file. The process can be seen in Figure 3 .

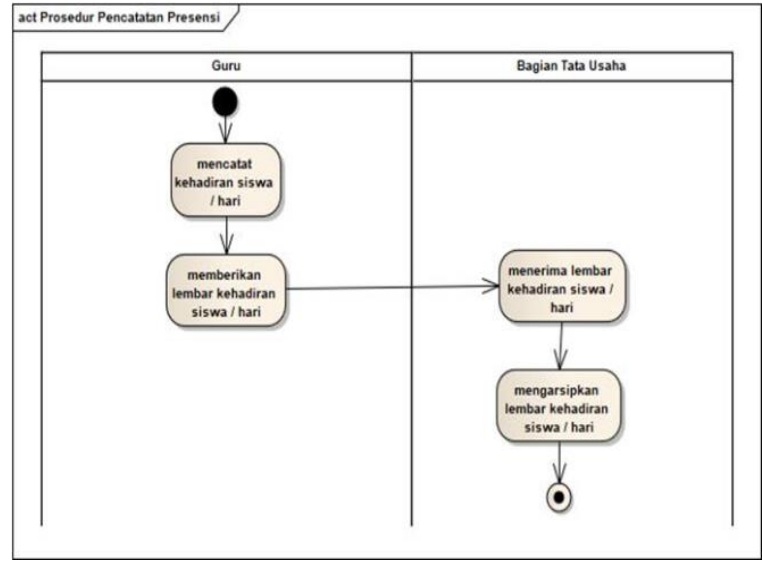

Figure 3 Activity Diagram of the Presence Record Procedure

\section{Presence Recapitulation Procedure}

At the end of the semester, 1.5 weeks before the exam, each teacher will make a recapitulation of the attendance of their class students and record the number of attendance of each student in the student absence book. The handbook is then handed over to the administration staff. The process can be seen in Figure 4 .

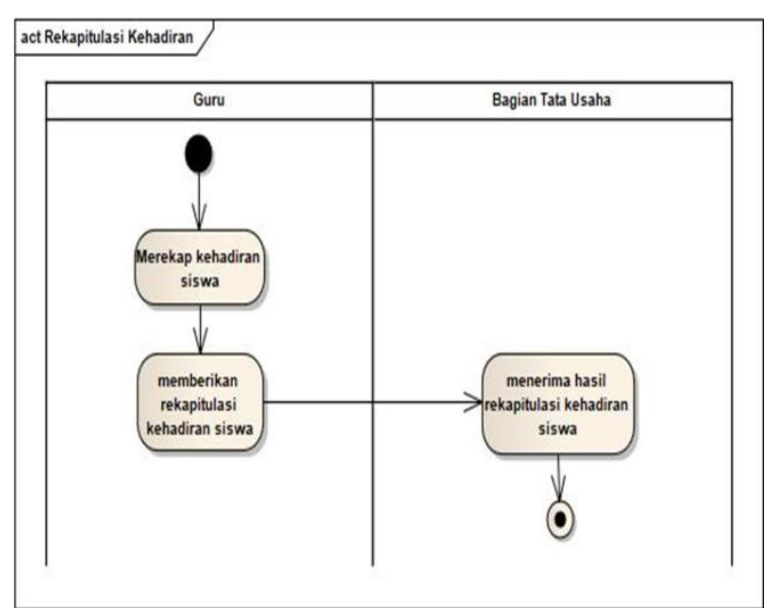

Figure 4 Activity Diagram of the Presence Recapitulation Procedure

3. Procedure for Making Attendance Reports

Based on the recapitulation of student attendance, the teacher then puts it in each student's report card. Based on the recapitulation of student attendance as well, the administration staff made a report on student attendance which was then submitted to the principal of Taman Siswa Bogor Middle School. The process can be seen in Figure 5. 


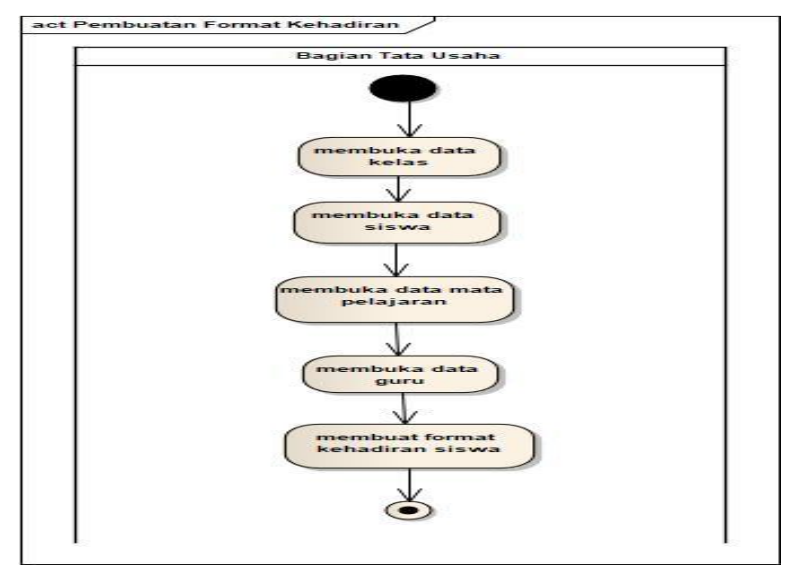

Figure 5 Activity Diagram Making Attendance Reports Procedure

4. Procedure for Making Attendance Format Administrative Staff is the part that manages all student data, teacher data, class data, subject data, and student attendance report formats. Initially, the Administrative Staff opens class data to view class members from student data. The Administrative Staff then opens subject data for the class and looks for teachers who teach each subject by opening the teacher data. Administrative staff then format student attendance based on these data. The process can be seen in Figure 6.

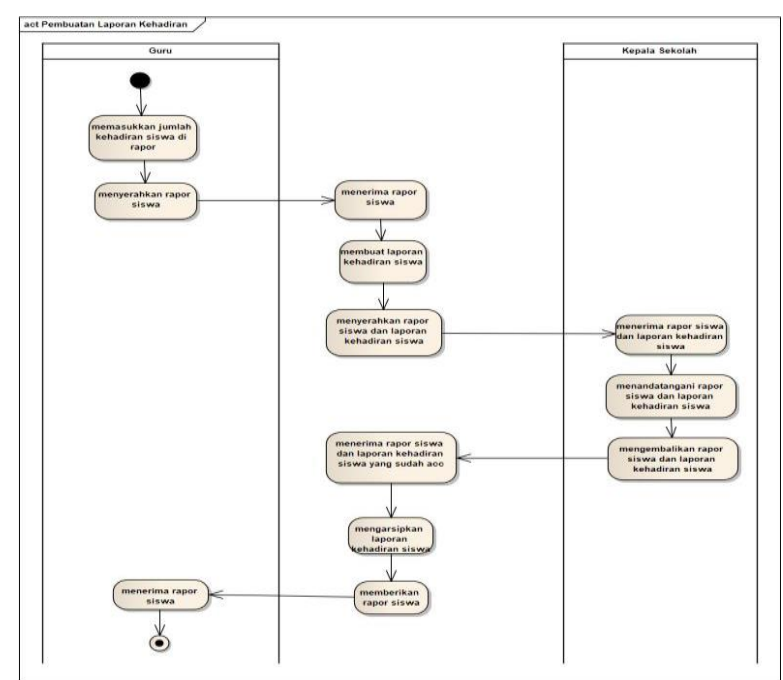

Figure 6 Activity Diagram procedure for Making Attendance Format

\section{Data Collection Techniques}

Before a conventional system is changed into an information system, the data collection process is carried out by:

1. Direct observation / Observation

Systems analysts observe the process of recording attendance, recording data to reporting student attendance that takes place at Bogor Taman Siswa Middle School.

2. Interview

Systems analysts collect information from sections involved in student attendance systems. The results of this interview produce the requirements for the new student attendance information system.

3. Literature Study

Reliable sources originating from books on information systems development and journals relating to the design of a presence information system are the basis for the design of this presence information system.

\section{Data analysis technique}

Based on information collected through direct observation, interviews and literature study, it can be described that the problems faced by Taman Siswa Junior High School in the presence system that are currently running are:

1. Student Presence System is currently still manual, does not use the application program and good data storage so that paper documents are often lost due to negligence of the teacher or administrative staff.

2. The process of recording attendance is still by calling students' names one by one so that it takes about 15-20 minutes.

3. The process of recapitulating student attendance also takes a long time, about 1 week, and is only done by one administrative staff member so that it burdens the task of section

4. Stacking of student attendance documents per class that require adequate storage.

\section{RESEARCH RESULTS AND DISCUSSION}

The steps in the RAD (Rapid Application Development) Model are also carried out by carrying out several steps, namely:

\section{Business Modeling}

Based on needs analysis, the study then proceeded with making a proposed system procedure that would overcome the problems that exist in the student presence system that runs at this time. The proposed presence attendance system procedure consists of:

1. Initial Presence Procedure in Class

The teacher who teaches the subject at the specified time will open the attendance page of the subject by entering the login code (nip and password) then giving a checklist to the subject 
listed on the presence page. The teacher then conducts his teaching activities to completion.

1. Procedure News Event Teaching

The teacher who has finished teaching will make an official report about the discussion of the material conducted on that day and provide feedback or input for the condition of the learning facility operated that day.

2. Final Attendance Procedure in Class

The teacher then calls each student's name listed on the presence page and then provides a checklist for his attendance. If the student is absent and there is a statement accompanying the reason for his absence, the teacher fills in the student information column. After completing the student's presence on that day, the teacher then confirms all the data that has been input.

3. Procedure for Making Presence Reports per month

Every 1 week before UTS and UAS, the Administration section will make a recapitulation report on student attendance based on student attendance every day. Requirements for student participation in midterm and final exam are determined by the percentage of student attendance of $90 \%$ of the total meetings before midterm and final exam. This report will then be given to the Principal for approval and will then be announced to students and parents through the Whatsapp Group.

\section{Data Modeling}

Database design that is formed, is presented in the Entity Relationship Diagram in Figure 7 and Logical Record Structure in Figure 9

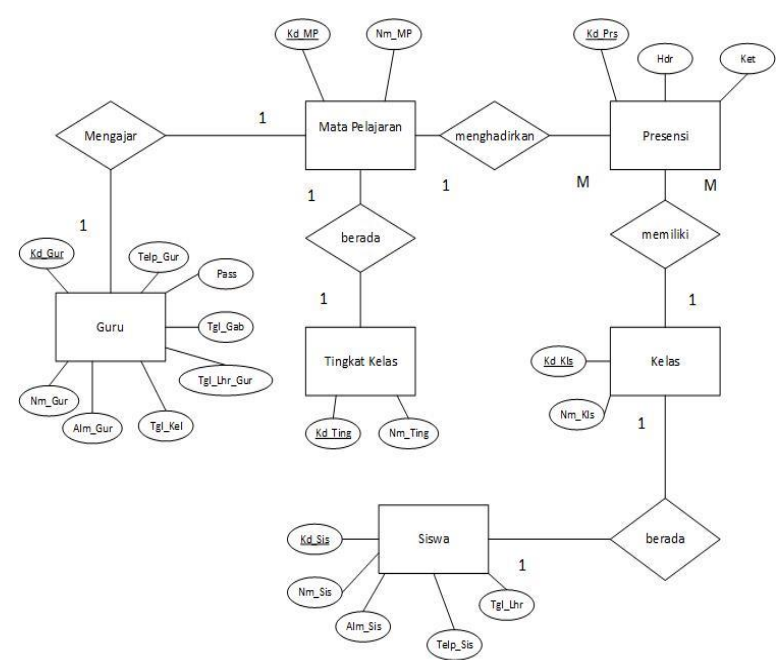

Figure 7 ERD Proposed System
From the ERD formed, then a Logical Record Structure is made which will be the basis for making several tables in the database.

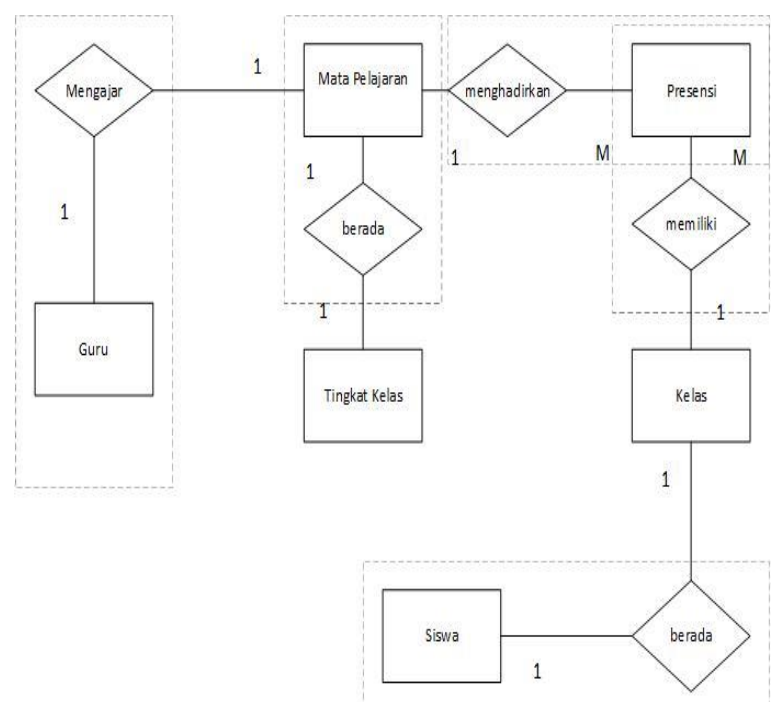

Figure 8 ERD Transformation Process into LRS

In the process of transforming ERD into LRS, cardinality in ERD plays an important role in determining the direction of merging one entity to another.

Explanation:

1. In the relationship between the Teacher entity and the Subject entity having 1: 1 cardinality, the direction of incorporation to the Teacher entity is because the Subject entity is very dependent on the Teacher entity

2. In the relationship between Subjects and ClassLevel entities that have 1: 1 cardinality, the direction of incorporation into the Subjects entity is because Class-Level entities depend on Subject-entity entities

3. In the relationship between Subject and Presence entities that have cardinality 1: $\mathrm{M}$, the direction of incorporation into the Presence entity is because this entity has a dominant cardinality

4. In the relationship between a Presence entity and a Class entity that has 1: M cardinality, the direction of incorporation into the Presence entity is because this entity has a dominant cardinality.

5. While the relationship between Class entities and Student entities that have a cardinality of $1: 1$, the direction of incorporation into the Student entity is because the Class entity depends on the Student entity. 
The transformation process produces a logical relationship between the 6 entities illustrated in Figure 9 below.

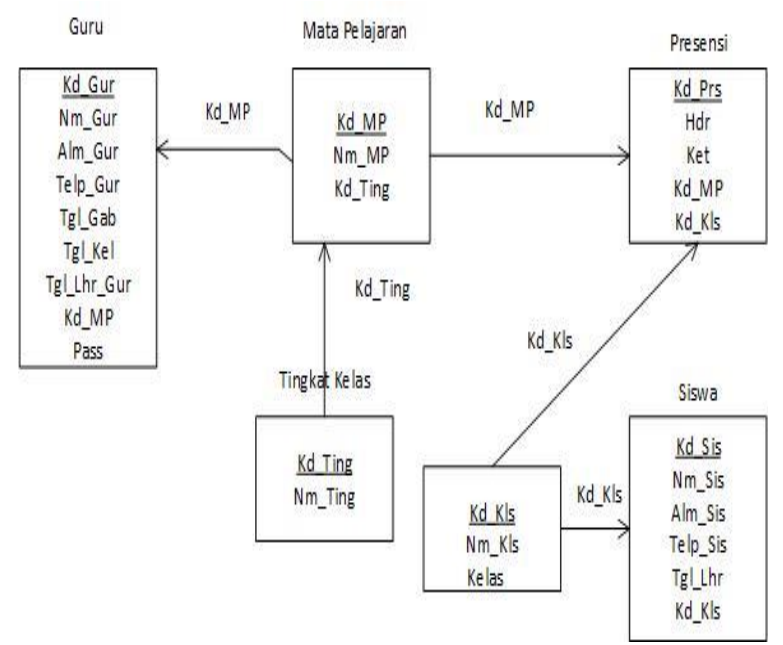

Figure 9 LRS Database Design

From the ERD and LRS that were formed, this Presence system has a Class Diagram illustrated in Figure 10 below entity is because the Class entity depends on the Student entity.

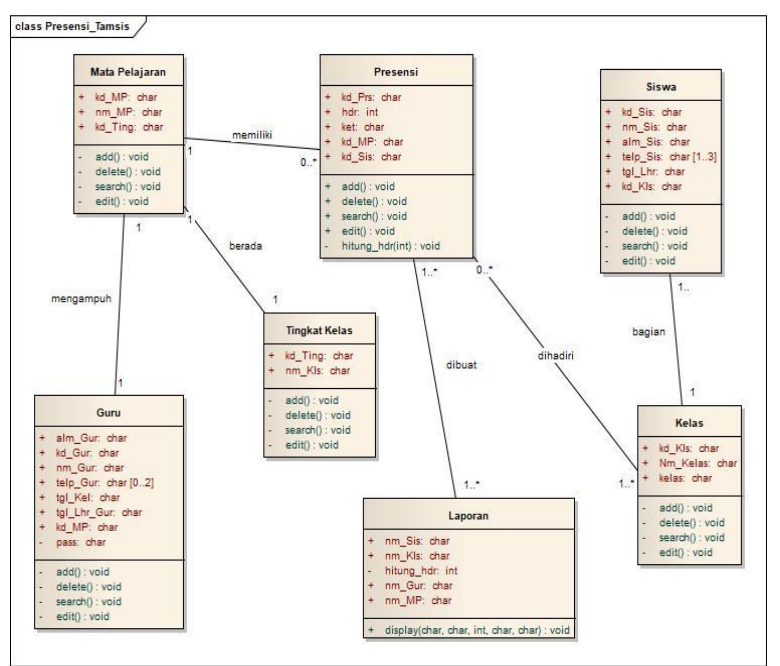

Figure 10 Class Diagram of Proposed Presence

System of Taman Siswa Middle School Students

\section{Process Modeling}

In this step, the business process that has been described in business modeling through the procedures carried out then explained in detail the SiPreSi function for each actor involved in it. The SIPreSi function that can be run is shown in the use case diagram in Figure 9 and Figure 10 below:

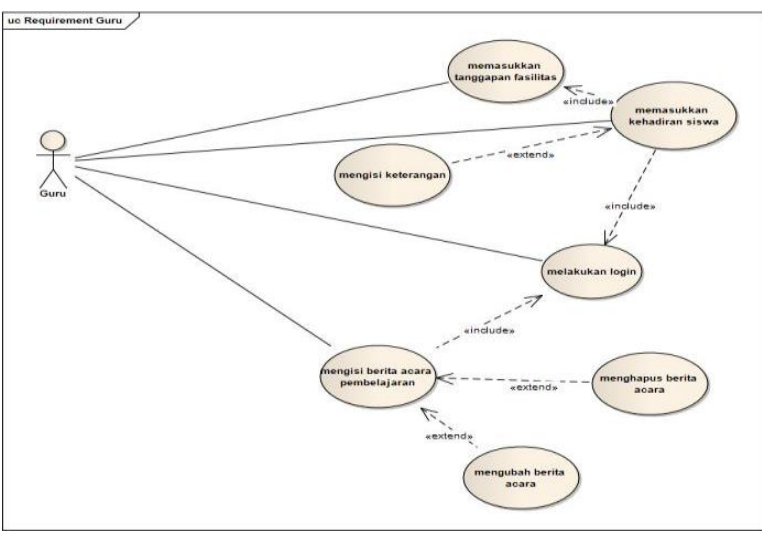

Figure 11 Use Case Diagram of a Proposed System for Teacher Facilities

In figure 11, it is explained that SIPreSi provides login facilities to enter the system before running other facilities. Facilities that are also available for teachers in SIPreSi are: filling in the minutes of learning which also provides optional facilities such as deleting the minutes and changing the minutes that have been entered. The main facility that must be run by teachers in SIPreSi is to include student attendance. If the student is absent, the information column is filled in to explain the reason for the student's absence. The system also provides facilities to fill responses about room conditions, learning equipment and other aids used in the teaching and learning process.

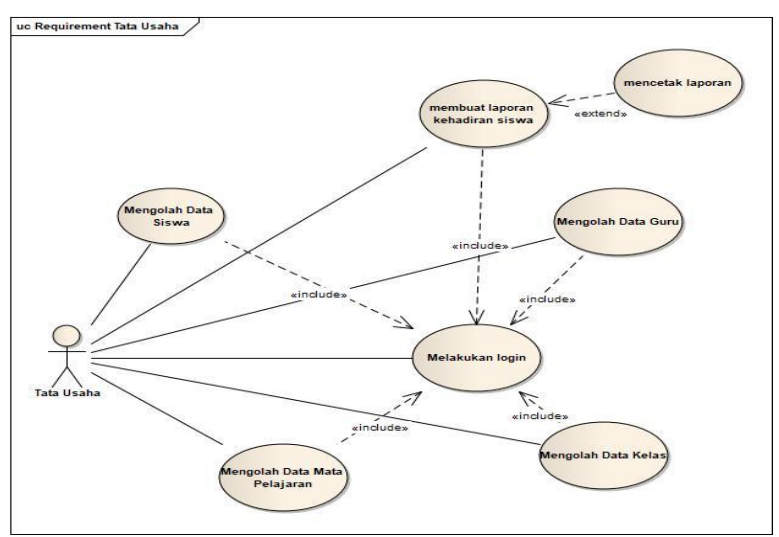

Figure 12 Use Case Diagram of a Proposed System for Administrative Facilities

In Figure 12 the facilities provided by the system for the Administration section are described. Login must be done first to enter into SIPreSi. Facilities for class data processing, teacher data processing, student data processing, and subject data processing are given for the Administration section. Do not forget the facility of making daily and monthly attendance reports provided by this system along with the means of printing the report. 


\section{Application Making}

At this stage, the application display is made using Microsoft Visual Basic 6.0. Here are a few looks:

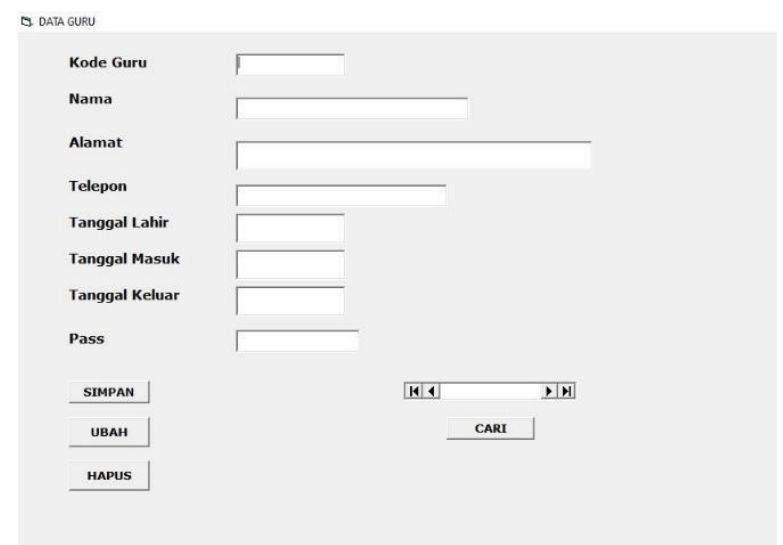

Figure 13 Form Input for Teacher Data

In Figure 13, the Form for entering teacher data is provided by the system with the save, delete, change and search action for teacher data that has been entered first.

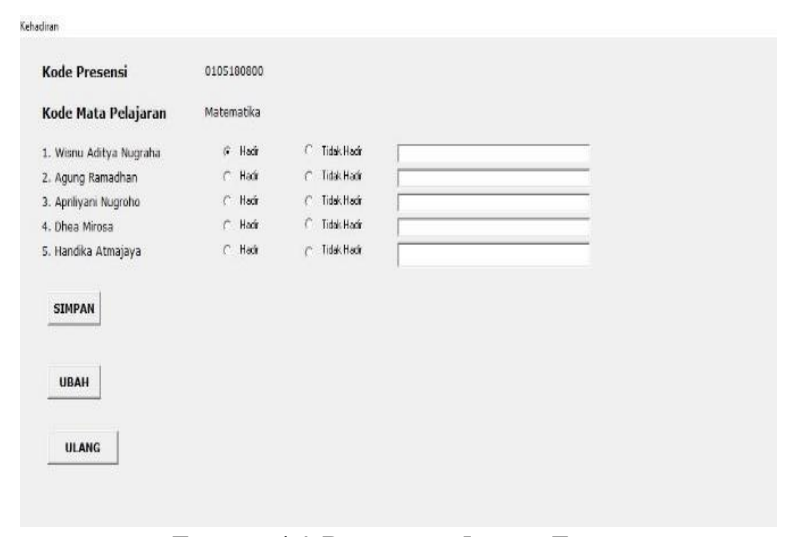

Figure 14 Presence Input Form
In Figure 14, the teacher enters the data of students who are present or not present by filling in the information column if the student is absent. Presence codes appear automatically with the pattern: date-month-year-hour, for example: 0105180800. '01' explains 1, '05' explains May, '18' explains 2018, '0800' explains 8:00 am when the teacher enter the system. While the name of the subject appears automatically due to the teacher code entered in Figure 15 below.

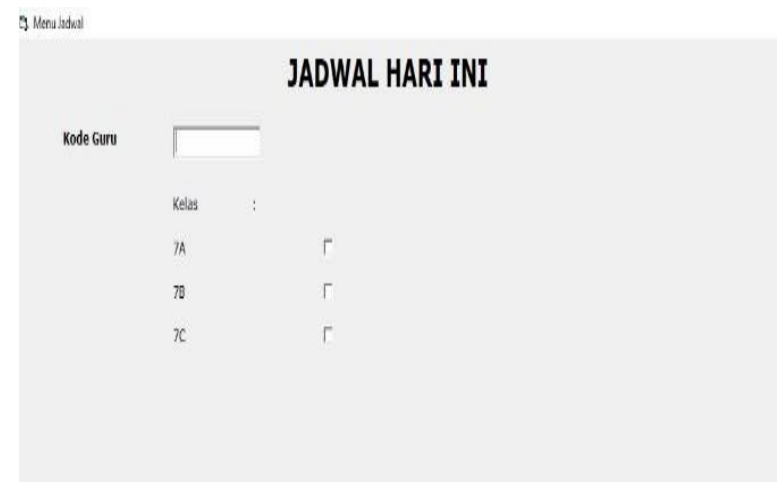

Figure 15. Schedule Selection Form

In Figure 15, the teacher code must be entered before the attendance form is displayed. By entering the teacher code and selecting the class to be taught, the attendance form for the class will appear along with the names of all class members.

\section{Testing and Substitution}

The next step is to test each form that is created. Testing uses the Black Box Testing method where each form will be inputted and then the results of the input are seen. This test will produce output but does not check the truth of the output produced. The testing process can be seen in table 1 below.

Table 1. Black Box Testing Results on the Teacher Form

\begin{tabular}{|c|c|c|c|c|c|}
\hline No. & Testing scenario & Test case & Expected Results & Test Result & Conclusion \\
\hline 1. & $\begin{array}{l}\text { Enter the existing } \\
\text { teacher code }\end{array}$ & ode Guru : AY01 & $\begin{array}{l}\text { The system will reject and } \\
\text { display "Teacher code } \\
\text { already exists" }\end{array}$ & $\begin{array}{l}\text { According to } \\
\text { expectations }\end{array}$ & Valid \\
\hline 2. & $\begin{array}{l}\text { Enter the doctor code } \\
\text { that does not yet exist }\end{array}$ & Kode Guru : AB12 & $\begin{array}{l}\text { The system will accept and } \\
\text { the cursor will move to the } \\
\text { name column }\end{array}$ & $\begin{array}{l}\text { According to } \\
\text { expectations }\end{array}$ & Valid \\
\hline 3. & $\begin{array}{l}\text { one of the fields is } \\
\text { missing, except for the } \\
\text { 'exit date' column, click } \\
\text { the save button }\end{array}$ & $\begin{array}{l}\text { Kode Guru : AB12 } \\
\text { Nama : Bambang } \\
\text { Alamat : Bogor } \\
\text { Telepon : (kosong) } \\
\text { Tanggal Lahir : 01-01-1992 } \\
\text { Tanggal Masuk : 25-09-2017 } \\
\text { Tanggal Keluar: (kosong) } \\
\text { Pass : } 123456\end{array}$ & $\begin{array}{l}\text { The system will reject and } \\
\text { display "Data not yet } \\
\text { complete" }\end{array}$ & $\begin{array}{l}\text { According to } \\
\text { expectations }\end{array}$ & Valid \\
\hline 4. & $\begin{array}{l}\text { all columns are filled, } \\
\text { except the 'exit date' } \\
\text { column, click the save }\end{array}$ & $\begin{array}{l}\text { Kode Dokter : AB12 } \\
\text { Nama : Bambang } \\
\text { Alamat : Bogor }\end{array}$ & $\begin{array}{l}\text { The system will receive and } \\
\text { display "Data has been } \\
\text { saved" }\end{array}$ & $\begin{array}{l}\text { According to } \\
\text { expectations }\end{array}$ & Valid \\
\hline
\end{tabular}




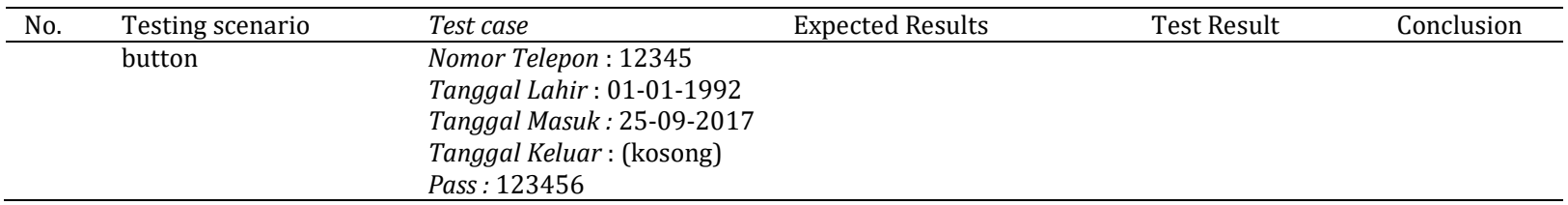

\section{CONCLUSIONS AND SUGGESTIONS}

\section{Conclusions}

This pre-prepared SiPreSi will help teachers and the administration section in making student attendance reports that were previously done manually so that they can overcome problems in data storage and processing. This SiPreSi will also assist parents in monitoring the presence of their children in each subject given through the daily attendance report sent by the administrative staff through social media groups.

\section{Suggestions}

The author hopes that this SiPreSi is supported by the foundation to be further developed into an Android-based application program so that it makes it easier to monitor parents of Taman Siswa Bogor Middle School students.

\section{REFERENCE LIST}

Darmawan, A., Yuliawati, D., Marcella, O., \& Firmandala, R. (2016). Sistem Absensi dan Pelaporan Berbasis Fingerprint dan SMS Gateway. Explore: Jurnal Sistem Informasi Dan Telematika, $7(1)$. https://doi.org/10.36448/jsit.v7i1.769

Hanafi, H. (2017). Konsep Penelitian R \& D Dalam Bidang Pendidikan. Saintifika Islamica: Jurnal Kajian Keislaman, 4(2), 129-150. http://jurnal.uinbanten.ac.id/index.php/sain tifikaislamica/article/view/1204

Haq, M. S. (2016). Pengembanagan Aplikasi Presensi Pegawai Berbasis Fingerprint. Jurnal Dinamika Manajemen Pendidikan, 1(1), 3440.

https://doi.org/10.26740/jdmp.v1n1.p34-40
Hermanto, H., \& Jollyta, D. (2019). Monitoring Presensi Siswa dan Guru Berbasis RFID dan Sms Gateway. Jurnal Mahasiswa Aplikasi Teknologi Komputer Dan Informasi, 1(1), 2631.

http://www.ejournal.pelitaindonesia.ac.id/J MApTeKsi/index.php/JOM/article/view/387

Irnawati, O., \& Listianto, G. B. A. (2018). Metode Rapid Application Development (RAD) pada Perancangan Website Inventory Pt. Sarana Abadi Makmur Bersama (S.A.M.B) Jakarta. Evolusi: Jurnal Sains Dan Manajemen, 6(2), 12-18.

https://doi.org/10.31294/evolusi.v6i2.4414

Kusaeri, W. R., Juliana, P., \& Pratama, R. R. (2018). PERANCANGAN SISTEM INFORMASI PENJUALAN MENGGUNAKAN METODE RAPID APPLICATION DEVELOPMENT (RAD) DI PABRIK GENTENG UUN SUPER JATIWANGI. PROSIDING SEMNASTEK 2018, 1-8.

https://jurnal.umj.ac.id/index.php/semnaste $\mathrm{k} /$ article/view/3457

Subiantoro, S., \& Sardiarinto, S. (2018). Perancangan Sistem Absensi Pegawai Berbasis Web Studi Kasus: Kantor Kecamatan Purwodadi. Jurnal Swabumi, 6(2), 184-189. https://doi.org/10.31294/swabumi.v6i2.486 8

Zebua, T., \& Pristiwanto, P. (2017). Sistem Informasi Absensi Mahasiswa STMIK Budi Darma Berbasis Mobile. Konferensi Nasional Teknologi Informasi Dan Komputer (KOMIK), I(1), 107-111. https://www.ejurnal.stmikbudidarma.ac.id/index.php/komik/article/vi ew/480 